\title{
In Defense of Basic Science Funding: Today's Scientific Discovery Is Tomorrow's Medical Advance
}

\author{
Marc Tessier-Lavigne \\ The Rockefeller University, New York
}

\begin{abstract}
In this address, I will discuss the importance of basic science in tackling our health problems. I will also describe how the funding cuts are damaging our economic competitiveness and turning our young people away from science.
\end{abstract}

\begin{abstract}
merica's last century has been a glorious Astory of leadership and innovation. That leadership has been built on a powerful partnership of our basic research scientists with our innovative companies - a partnership forged virtually entirely with Federal funds and with deep public support. Basic scientists, working in our universities and research institutes, and supported by government agencies like NIH, churn out discoveries that our companies build on to develop therapies and cures for patients with serious diseases.

History shows that this public-private alliance works, and that our public investment in basic research pays. Mortality from heart disease and stroke has been cut in half in 40 years. HIV/AIDS has been transformed into a disease that's manageable without hospitalization. The human benefits from these investments are enormous, as are the economic benefits, estimated in the trillions of dollars.

But huge health challenges remain. Death rates from cancer remain stubbornly high. Infectious diseases are becoming resistant to our arsenal of antibiotics. Chronic diseases like Alzheimer's and diabetes are on the rise. The suf-
\end{abstract}

fering is immense, and the costs of care could bankrupt us. In the absence of a therapy, the cost for Alzheimer's alone is estimated to grow to a trillion dollars a year by 2050 because of the aging of the population.

The only way to contain both the human and the economic impact of these diseases on society is through sustained investment in science. Today's scientific discovery is tomorrow's medical advance.

The great news is that we're in a golden age of disease research, thanks to the sequencing of the human genome and the development of other powerful technologies. If we make the investments, we can understand why tumors spread, we can understand why nerve cells die in Alzheimer's disease, we can unlock the secrets of our immune system. And that knowledge is needed for us to conquer cancer, to defeat dementia, and to develop vaccines for HIV.

So we now find ourselves at a time of huge medical need-but also enormous scientific opportunity. And yet, we're pulling back! Our basic science investment as a percentage of GDP is at its lowest in 50 years. NIH funding has been flat for a decade and has lost $20 \%$

Copyright (C) 2013 Cold Spring Harbor Laboratory Press; all rights reserved; doi: 10.1101/cshperspect.a019554

Cite this article as Cold Spring Harb Perspect Med 2013;3:a019554 
M. Tessier-Lavigne

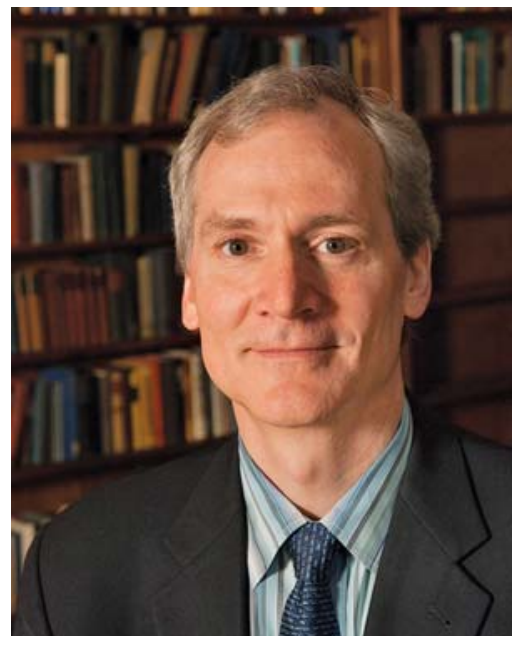

of its purchasing power because of inflation. This has put enormous stress on our scientists who spend more time raising money than doing research, and are increasingly being driven from our shores in search of better funding. Most worrying, young people are being discouraged from a research career, which will lead to the long-term decline of our scientific enterprise. Make no mistake: it is possible to ruin our scientific community. If we continue on this path, we will kill the goose that laid the golden egg.

And now, that enterprise, already battered for 10 years, is taking another blow from the $5 \%$ funding cut from the sequester. It's fair to ask: what do we get for that? Last year, we spent $\$ 100$ per citizen per year supporting NIH, so a $5 \%$ cut is a $\$ 5$ savings. But compare that to the $\$ 8,000$ we spend per citizen per year on health care, and you can see that the NIH cut won't make a meaningful difference to our overall fiscal situation. But it will cause real damage to our ability to tackle tomorrow's health care problems and health costs.

Cutting research is a form of Catch-22 politics. To solve one problem you weaken its only real solution: basic science.
Some may wonder, won't industry pick up the slack in basic research? As one who spent close to a decade in industry, I can say from experience that the answer is no. Return on investment in basic research takes too long from a business perspective. It already takes well over a decade and a billion dollars to go from an existing scientific insight to a drug on the market, and industry can't and won't fund the basic research that it builds on. Only government has the necessary long-term perspective, looking out not just 10 years but 20, and beyond.

Others may ask, why not leave basic research to other nations, which U.S. companies could then exploit? The answer is: it won't work that way. Companies locate near the sources of innovation, which provide the skilled workforce and the flow of ideas needed for drug and vaccine discovery. If we gut our basic science effort, innovative companies will relocate to more vibrant scientific communities in other nations that are making the needed investments.

The path is clear: we must renew our investment in basic science research to reach for a brighter future. This isn't a partisan issue. Recently, both President Obama and House Majority Leader Cantor made stirring cases for the importance of investment in basic science to tackle the grand challenges facing society. Let's join with them to urge both parties to come together to reverse the cuts to basic science research and to make that bright future ours.

This is an edited transcript of a speech given at the Rally for Medical Research held in Washington, D.C. on April 8, 2013 that was based on a Forbes magazine article published online on March 6, 2013 ("Legendary Drug Industry Executives Warn U.S. Science Cuts Endanger the Future," by Drs. M. Tessier-Lavigne, R. Vagelos, and E. Zerhouni, see http://www.forbes. $\mathrm{com} /$ sites/matthewherper/2013/03/06/drug-industry-greats-say-the-u-s-must-reverse-the-cuts-to-ourinvestment-in-science/). It has been adapted with permission. 


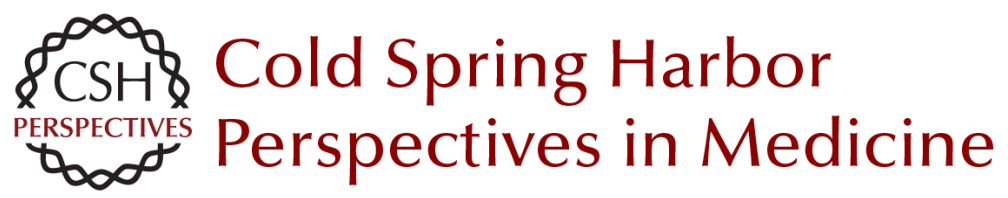

\title{
In Defense of Basic Science Funding: Today's Scientific Discovery Is Tomorrow's Medical Advance
}

\author{
Marc Tessier-Lavigne
}

Cold Spring Harb Perspect Med 2013; doi: 10.1101/cshperspect.a019554 originally published online May 17,2013

Subject Collection

For additional articles in this collection, see http://perspectivesinmedicine.cshlp.org/cgi/collection/ 